\title{
An Analysis of English Teaching Strategies in Universities and Colleges from the Perspective of Aesthetics
}

\author{
Xuelian Wang * \\ School of Foreign Language of Xi'an University \\ Xi'an, China \\ 2523993234@qq.com \\ * Corresponding Author
}

\begin{abstract}
Language is the carrier of culture, and the expressions of people's thoughts cannot be separated from human nature, so that there is a kind of internal integrity between English teaching and aesthetics. Therefore, the fundamental goal of English teaching in universities and colleges is to make creative use of aesthetic teaching means and English teaching materials full of emotions in order to show beauty of English to students in the process of English teaching in universities and colleges. This paper is a documentary and qualitative research. It can be resulted from the analysis that aesthetic consciousness are embodied in English teaching and learning in universities and colleges in many aspects such as beauty of sound, beauty in form, beauty in meaning, beauty in rhetorical devices and beauty in emotions, and aesthetic education in English teaching in universities and colleges help students learn English in a happy mood and automatic way.
\end{abstract}

Keywords- English teaching strategies; universities and colleges; aesthetics

\section{INTRODUCTION}

Education is a kind of art and spiritual career, so that the aim of English teaching in universities and colleges is not help students grasp language skills in listening, speaking, reading, writing and translating, but also students' taste of beauty should be cultivated through language in which foreign culture and mode of thinking can be reflected, so that students can have a better understanding of deep social culture of English through the surface language materials. In the process of English teaching in universities and colleges, teachers should make full use of aesthetic means connect students' cognitive world with emotional and cultural world of English so that English teaching in universities and colleges should take language education and aesthetic education of students in consideration.

\section{LITERATURE REVIEW}

\section{A. Connotation of Aesthetic Education in English \\ Teaching in Universities and Colleges}

Students in universities and colleges have a stronger ability aesthetics, and they have more life experience so that they will have a better understanding of English. The connotation of aesthetic education in English teaching in universities and colleges is to explore the characteristics of English in the process of teaching activities, and students can feel beauty, appreciate beauty as well as create beauty in the interactive process of knowledge and emotions through artistic teaching mode and real emotional communications. In this way, aesthetic concept should be embodied in teaching purpose, teaching contents, teaching procedures and teaching methods, and English teachers in universities and colleges should play a positive role in the cultivation of students' aesthetic ability in many aspects such as teaching behaviors, teaching languages, teaching personalities and so on.

\section{B. Humanistic Theory}

The representatives of humanistic theory Maslow and Rogers highlighted that teaching is human oriented and student-centered, and the fundamental task of learning is to promote overall development of students' personalities, namely that students' potentials of love, cooperation, creativity and aesthetics can be developed. As a result, aesthetic education in universities and colleges is to arouse the emotional factors of students to the greatest extent in the pleasant and tense interactive learning atmosphere, so that both intellectual as well as emotional creativities of students can be developed.

\section{Reception Aesthetics Theory}

Jauss and Issel are the major representatives of reception aesthetics theory, and they consider that literary works are created for readers and appreciators, and literary works can realize their values after aesthetic reception activities. Readers are the subjects in this process of reception, and reception of literary works can be understood as a kind of dialogue between the author and readers, namely receptors. It is the same that English teaching in universities and colleges is also a process of conversation in which students are the receptors and subjects, teaching materials are the objects of aesthetics, while teachers are the transmitters of reception activities. 


\section{SPECIFIC EMBODIMENTS OF AESTHETIC CONSCIOUSNESS IN ENGLISH TEACHING IN UNIVERSITIES AND COLLEGES}

\section{A. Sound Beauty in English Teaching}

Beauty is actually an important element of people's daily life, and it is also a necessary factor used by people in the process of communication. The intensity, speed, pitch, tone of voice can show some implicit meanings, convey some information as well as express certain emotions and feelings of people. Therefore, full use of sound beauty of English in universities and colleges such as English beauty in rhythm can arouse students' interest in learning English so that they will have the motivation of imitating as well as have pleasure of using English in communication. Therefore, teachers in universities and colleges can make full use of authentic resources of English sound beauty of teaching materials and internet resources in order to let students imitate and appreciate beauty of sound in English learning. For example, the song "Showing me the meaning of being lonely" shocked the heart of many students with authentic English and rhythm beauty of Vicissitudes. There are few authentic, bright and pleasant English songs in the film The Sound of Music, these songs can not only give students a kind of aesthetic feeling, but also they can learn some authentic English expressions at the same time.

\section{B. English Meaning Beauty in English Teaching}

The use of polysemy is commonly seen in English, it means that the same form of a word has many meanings. The purpose and function of this is to reduce the number of English words and reduce people's burden of memorizing a large number of English vocabularies, and it is the embodiment of economy principle of people's language as well. From the angle of cognitive linguistics, the inner motivation of the emergence of the phenomenon polysemy is metaphor and metonymy, and they are two basic modes of thinking of people to recognize the objective world. As a result, English meaning beauty and beauty in rhetorical devices can be used in English teaching in universities and colleges. For example.

1) Life is a journey.

This is actually metaphor in English, and it makes use of meaning to reflect the beauty of English learning in universities and colleges. In other words, there are similarities between the two things, and they both have travelers, starting points and ending points so that students in universities and colleges will be interested in this, and their English learning effect will be improved at the same time.

2) I like reading Faulkner.

This is an obvious example of metonymy, Faulkner is used to represent his works due to close relationship between Faulkner and his works. Students may be confused of the meaning of this sentence at the first point, but they will be attracted by its charm when they understand the real meaning of this English sentence, and this is called English aesthetics of meaning and rhetorical devices. Statistics show that most students in universities are in favor with learning of figure of speech, and 60 students are interviewed.

\begin{tabular}{|l|l|l|l|l|}
\hline $\begin{array}{l}\text { Students' } \\
\text { attitude }\end{array}$ & $\begin{array}{l}\text { Very } \\
\text { like }\end{array}$ & Like & Dislike & $\begin{array}{l}\text { Very } \\
\text { dislike }\end{array}$ \\
\hline Number & 15 & 40 & 12 & 3 \\
\hline
\end{tabular}

Metaphor and metonymy created multiple meanings and freshness of language symbols, so that teachers in universities and colleges should bring them into English teaching in order to help students have a better understanding of development laws of lexical meanings of English words. In this way, students in universities and colleges can have understand the connotations of the same English word in different contexts and they can also deeply appreciate meaning beauty and beauty in rhetorical devices of English learning in universities and colleges.

\section{Emotional Beauty in English Teaching}

As a kind of language, English is the most important communicative tool of human beings, and people convey information as well as express their thoughts with the help of English. Besides, it can also be used to exchange emotions and feelings so that English learners will have emotional experience in the process of learning English. The cognitive ability and emotional experience of students in universities and colleges are in a higher level, so that they can have a better understanding of emotions and feelings contained in English. Therefore, emotional beauty of English can show the inner beauty of language, so that students in universities and colleges can gain nutrition in the process of learning English. At the same time, they can adapt their psychological state so that they can learn English and do other things in a good emotion and mood. Therefore, out-of-class reading materials full of emotions are necessary in order to purify the souls and improve aesthetic consciousness of students in universities and colleges to some extent. For example, "The Portrait of a Teacher" simply shows the moving teacher-student relationship. The Last Leaf of $O$ Henry tells the friendship of three painters in difficulties. Three Days to See of Helen Keller shows her love of life and desire of light, so that students will have the same feeling and show sympathy for her. In the process of appreciating these literary works, students can learn beautiful language on one hand, and they can also cultivate their taste at the same time in the process of English learning.

\section{WAYS OF STRENGTHENING AESTHETIC EDUCATION IN ENGLISH TEACHING IN UNIVERSITIES AND COLLEGES}

This part proposes several ways of strengthening aesthetic in English teaching in universities and colleges in the perspectives of teachers, students and classroom activities.

\section{A. Strengthening Aesthetic Consciousness of Teachers' Professional Qualities}

Aesthetic consciousness of teachers' professional qualities is reflected in teaching manners, blackboard-writing and teaching atmosphere, elegant teaching manners, beautiful voice, clear blackboard 
writing as well as harmonious classroom environment can help students gain aesthetic feelings from classroom learning so that they will have strong interest in participating in classroom learning of English. Besides, aesthetic consciousness of teachers is also reflected in rich knowledge, noble personalities as well as excellent teaching skills, so that students will show respect for teachers and their desire of learning English in universities and colleges will be also motivated as well.

\section{B. Improving Students' Aesthetic Consciousness of Cultural Qualities}

Students in universities and colleges should consciously cultivate their aesthetic attitudes, aesthetic abilities as well as aesthetic tastes in the process of English learning. They should have a correct attitude toward English learning, namely that and learning in universities and colleges in many aspects such as beauty of sound, beauty in form, beauty in meaning, beauty in rhetorical devices and beauty in emotions, and aesthetic education in English teaching in universities and colleges help students learn English in a happy mood and automatic way. Besides, personalities and overall development of students in universities and colleges can be also promoted at the same time.

\section{Strengthening Aesthetic Consciousness of Classroom Teaching Activities}

The atmosphere of classroom teaching in universities and colleges should be relaxed and free and creative, so that classroom activities should be enriched so as to improve students' aesthetic consciousness in the process of English learning. Firstly, discussions can be used in teaching Five Symbols of American Culture in order to give students freedom to express their thoughts. Secondly, classroom debates can be applied in universities and colleges in order to show their speed of thinking, improve personal charm, enhance their confidence as well as improve their comprehensive ability of using English. Last but not the least, role plays can be also used in English teaching in universities and colleges. students can feel the charm of English through role plays in relatively real context, so that aesthetic education in universities and colleges can be enhanced at the same time.

\section{CONCLUSIONS}

In conclusion, English teaching in universities and colleges should be not only the cultivation of language skills, but also it is a kind of humanistic education, and its aim is to strengthen the cultivation of aesthetic consciousness in the process of English teaching and learning. All in all, English teachers in universities and colleges should integrate English teaching and aesthetic in an organic way beautify the souls of students, strengthen their aesthetic consciousness in English learning as well as improve students' comprehensive ability of using English in daily life.

\section{REFERENCES}

[1] Chomsky, N. On Nature and Langue [M]Cambridge: Cambridge University Press, 2002

[2] Dai Weidong. Foreign Language Teaching and Teacher Professional Development: Theory and Practice [M]. Shanghai Foreign Language Education Press, 2006.

[3] Devitt, M \& Sterelny, K. Language and Reality: An Introduction to the Philosophy of Language [M]Oxford:Basil Blackwell, 1987

[4] Iser. Wolfgang. The Acting of Reading: A Theory of Aesthetic Response [M]. Baltimore: Jones Hopkins University Press, 1978.

[5] Jauss, H. R. Towards an Aesthetics of Reception [M].New York Columbia University Press, 1982.

[6] Lakoff, G. \& M. Johnson. Metaphors We Live By. Chicago: University of Chicago Press, 1980.

[7] Leila Christenbury, Making the Journey Being and Becoming a Teacher of English Language Arts [M], United States of 